\title{
GLOMUS CLAROIDEUM AND G. SPURCUM, ARBUSCULAR MYCORRHIZAL FUNGI (GLOMEROMYCOTA) NEW FOR POLAND AND EUROPE, RESPECTIVELY
}

\author{
JANusz BŁASZKowsKi, IwONA ADAMSKA, BEATA CZERNIAWSKA \\ Department of Plant Pathology, University of Agriculture \\ Slowackiego 17, 71-434 Szczecin, Poland \\ e-mail: jblaszkowski@agro.ar.szczecin.pl
}

(Received: August 3, 2002. Accepted: January 22, 2003)

\begin{abstract}
The ontogenetic development and morphological properties of spores of two species of arbuscular mycorrhizal fungi (Glomeromycota) of the genus Glomus, G. claroideum and G. spurcum, are described and illustrated. Spores of the two species were not earlier found in Poland, and this paper is the first report of the occurrence of G. spurcum in Europe.

In one-species pot cultures with Plantago lanceolata as the host plant, the mycorrhizae of G. claroideum consist of arbuscules, vesicles, as well as intra- and extraradical hyphae staining intensively with trypan blue. Glomus spurcum mycorrhizae were not recognized, because many attempts to establish one-species cultures of this fungus failed. Additionally, the distribution of both the fungi in the world is presented.
\end{abstract}

KEY WORDS: arbuscular fungi, Glomeromycota, mycorrhizae.

\section{INTRODUCTION}

Isolation of spores of arbuscular mycorrhizal fungi (Glomeromycota) from field-collected rhizosphere soils and those from trap cultures representing cultivated sites and maritime dunes of northern Poland revealed two species of the genus Glomus, G. claroideum and G. spurcum. Spores of G. claroideum were not earlier isolated from soils in Poland, although Turnau et al. (2001) revealed this fungus in roots of Fragaria vesca L. growing on a zinc-waste site near Chrzanów (southern Poland), following the use of a molecular taxon-specific primer. Glomus spurcum was not reported from Europe to date. Additionally, the few existing literature data suggest that the descriptions of morphological properties of spores of both G. claroideum and G. spurcum are incomplete and inconsistent. Therefore, the main aim of this paper is to describe and illustrate the morphological properties of spores of G. claroideum and G. spurcum coming from living pot cultures with soils of Poland and to compare them with those published to date. Additionally, the distribution of the two fungi in the world is presented.

\section{MATERIALS AND METHODS}

Collection of soil samples, establishment of trap and single-species pot cultures, as well as growth conditions are generally like those described previously (Błaszkowski and
Tadych 1997). Briefly, rhizosphere soils and roots of sampled plants were collected from a depth of $5-30 \mathrm{~cm}$ using a small garden shovel. In the laboratory, about 200-g subsamples were taken from each sample to determine the species of arbuscular fungi sporulating in the field. Then, the remaining soil-root mixtures were either air dried for 2 weeks and subsequently refrigerated at $4{ }^{\circ} \mathrm{C}$ or directly used to establish trap cultures. Trap cultures were established to receive a great number of living spores of different developmental stages and to initiate sporulation of species nonsporulating in field conditions. The growing substrate of the trap cultures was the field-collected material mixed with an autoclaved coarse-grained sand coming from maritime dunes adjacent to Świnoujście (pH 6.7; 12 and $26 \mathrm{mg}$ $\mathrm{L}^{-1} \mathrm{P}$ and $\mathrm{K}$, respectively). These mixtures were placed in $15 \mathrm{~cm}$ plastic pots $\left(1350 \mathrm{~cm}^{3}\right)$ and thickly seeded with host plants. The plant species trapping arbuscular fungi from cultivated soils were Plantago lanceolata L., Sorghum vulgare Pers. and Zea mays L., whereas only P. lanceolata trapped these fungi in cultures representing maritime dunes. Plants were grown in a greenhouse at $15-30^{\circ} \mathrm{C}$, with supplemental 8-16-h lighting provided by one SON-T AGRO sodic lamp (Philips Lighting Poland S.A.) placed $1 \mathrm{~m}$ above pots. The maximum light intensity was $180 \mu \mathrm{E} \mathrm{m}^{-2} \mathrm{~s}^{-1}$ at pot level. Plants were watered 2-3 times a week. No fertilization was applied during the growing period. Trap cultures were harvested at approximately 1-month intervals, beginning three months and ending five months after plant 
emergence. Spores were extracted by wet sieving and decanting (Gerdemann and Nicolson 1963). The presence of mycorrhizae was determined following clearing and staining of roots. Based on the experience of the authors of this paper and suggestions of Professor R.E. Koske, Rhode Island University, U.S.A., two changes were introduced to the original method given by Phillips and Hayman (1970). First, roots earlier cleared in $10 \% \mathrm{KOH}$ were acidified in $20 \% \mathrm{HCl}$ instead of $1 \% \mathrm{HCl}$ as in the original procedure. Second, the concentration of trypan blue was increased from 0.05 to $0.1 \%$.

Single-species pot cultures were established from about 50 to 100 newly formed spores stored before inoculation in water at $4^{\circ} \mathrm{C}$ for $24 \mathrm{~h}$. After removing soils debris, they were collected in a pipette and transferred onto a compact layer of roots of 10-14-day-old seedlings of $P$. lanceolata placed at the bottom of a hole of $\mathrm{ca} 1 \mathrm{~cm}$ wide and $4 \mathrm{~cm}$ deep formed in a wetted growing medium filling $8-\mathrm{cm}$ plastic pots $\left(250 \mathrm{~cm}^{3}\right)$. The growing medium was autoclaved sand from maritime dunes adjacent to Świnoujście, of chemical properties given above. Subsequently, the spores were covered with another layer of roots coming from 4-6 plants of the host. Finally, the roots and sandwiched spores were buried in the growing medium. The cultures were harvested after 4-6 months and spores extracted.

Developmental stages of the fungus were determined based on newly formed spores extracted from both trap and single species cultures, the latter being harvested at $\mathrm{ca} 20$ -30-day intervals.

Morphological properties of spores, their subcellular structures and developmental stages during differentiation were determined based on at least 100 spores mounted in polyvinyl alcohol/lactic acid/glycerol (PVLG; Koske and Tessier 1983) and a mixture of PVLG and Melzer's reagent $(1: 1, v / v)$. The spores represented all stages of differentiation of the fungus. The degree of maturity of spores was assessed based on their appearance under an Olympus SZX9 dissecting microscope. The main considered properties were colour and size of spores. Spores were crushed to varying degrees by applying pressure to the coverslip and then stored at $65^{\circ} \mathrm{C}$ for $24 \mathrm{~h}$ to clear their contents from oil droplets. Examination of so prepared specimens was performed using an Olympus compound microscope equipped with differential interference contrast optics.

Terminology of spore structure is that suggested by Spain et al. (1989), Stürmer and Morton (1997), and Walker (1983). Spore colour was examined under a dissecting microscope on fresh specimens immersed in water. Colour names were used according to Kornerup and Wanscher (1983). The specimens were mounted in PVLG on slides and deposited in the Department of Plant Pathology (DPP), University of Agriculture, Szczecin, Poland.

\section{DESCRIPTIONS OF THE SPECIES}

\section{Glomus claroideum Schenck et Smith}

Sporocarps unknown. Spores borne singly in the soil (Fig. 1); produced from straight sporophores. Sporophore coenocytic to sparsely septate; hyaline to yellowish white (4A2); (1.9-)4.4(-7.6) $\mu \mathrm{m}$ wide; with a wall (0.4-)0.5(-0.7) $\mu \mathrm{m}$ thick; bearing spores by swelling at hyphal tips. Mature spores pale yellow (4A3) to greyish orange (5B5); globose to subglobose; (95-)135(-190) $\mu \mathrm{m}$ diam; sometimes ovoid; $95-110 \times 110-160 \mu \mathrm{m}$; with a single subtending hypha (Figs $1,5,6)$. Subcellular structure of spores consists of one wall (Figs 4-6) with four layers (layers 1-4). The outermost layer 1 mucilagenous, hyaline, (1.5-)2.1(-2.8) $\mu \mathrm{m}$ thick, tightly adherent to layer 2 (Figs 2-6), staining pinkish white (11A2) to purplish red (14A8) in Melzer's reagent, usually absent in mature spores or present in the form of highly decomposed fragments (Figs 5, 6). Layer 2 semiflexible, hyaline, smooth, (2.2-)3.3(-3.9) $\mu \mathrm{m}$ thick, non-reactive in Melzer's reagent (Figs 2-4), deteriorating with age (Figs 5, 6). Layer 3 laminate (Figs 3-6), smooth, pale yellow (4A3) to greyish orange (5B5), composed of tightly adherent, very thin, $<0.5 \mu \mathrm{m}$ thick, sublayers; (2.9-)5.9(-8.1) $\mu \mathrm{m}$ thick. Layer 4 flexible, smooth, hyaline, (0.4-)0.5(-0.6) $\mu \mathrm{m}$ thick, usually separating from layer 3 of spore wall in crushed spores (Figs 4, 5), but attached to the inner surface of the laminate layer 3 of subtending hypha (Fig. 6). Most juvenile spores with wall layers 1 and 2 only (Fig. 2). Layers 3 and 4 form successively during the development of spores (Figs 3 , 4). Subtending hypha pale yellow (4A3) to greyish orange (5B5); straight or recurvate; cylindrical or funnel-shaped, rarely constricted; (8.3-)12.1(-15.4) $\mu \mathrm{m}$ wide at the spore base (Fig. 6). Wall of subtending hypha pale yellow (4A3) to greyish orange (5B5); (2.7-)3.7(-4.7) $\mu \mathrm{m}$ thick at the spore base; composed of three layers continuous with spore wall layers 1-3 (Fig. 6); layer 1 rarely present in mature spores. Pore occluded by layer 4 of the spore wall.

Collections examined: Poland. Szczecin, spores and root fragments from one-species cultures with $P$. lanceolata as the plant host, 15 May 2001, Błaszkowski J., 2356-2377, DPP.

Other materials examined: Spores from trap cultures with root-rhizosphere soils of Avena sativa L., Beta vulgaris L., Brassica napus L., B. oleracea L., Fragaria vesca L., Hordeum vulgare L., Secale cereale L., Triticum aestivum L., $x$ Triticosecale Witt., and Z. mays cultivated in western Pomerania in 1998-2000, Błaszkowski J., unnumbered collection.

Distribution and habitat: Glomus claroideum was the third most frequently occurring species among those recovered from 199 root-rhizosphere soil mixtures taken from under 10 plant species cultivated in 106 sites of the western Pomerania voivodeship. The plant species were A. sativa, $B$. vulgaris, $B$. napus, $B$. oleracea, $F$. vesca, $H$. vulgare, Secale cereale, T. aestivum, $x$ Triticosecale, and Z. mays. When spores recovered from field-collected root-rhizosphere soil mixtures and trap cultures were considered, this fungus ranked first in respect of the number of spores produced. The species of arbuscular fungi associated with $G$. claroideum in the field and trap cultures included Acaulospora paulinae Błasz., Archaeospora trappei (Ames et Linderman) Morton et Redecker, G. aggregatum Schenck et Smith emend. Koske, G. caledonium (Nicol. et Gerd.) Trappe et Gerd., G. constrictum Trappe, G. deserticola Trappe, Bloss et Menge, G. dominikii Błaszk., G. fasciculatum (Thaxter) Gerd. et Trappe emend. Walker et Koske, G. geosporum (Nicol. et Gerd.) Walker, G. laccatum Błaszk., G. mosseae (Nicol. et Gerd.) Gerd. et Trappe, and Scutellospora dipurpurescens Morton et Koske.

The chemical properties of the western Pomerania voivodeship soils were: $\mathrm{pH}, 4.4-8.0 ; \mathrm{N}(\%), 0.05-0.32$; $\mathrm{P}$ (mg/100 g of soil), 0.04-26.62, K, 3.32-36.71, and organic C (\%), 0.33-2.41. 

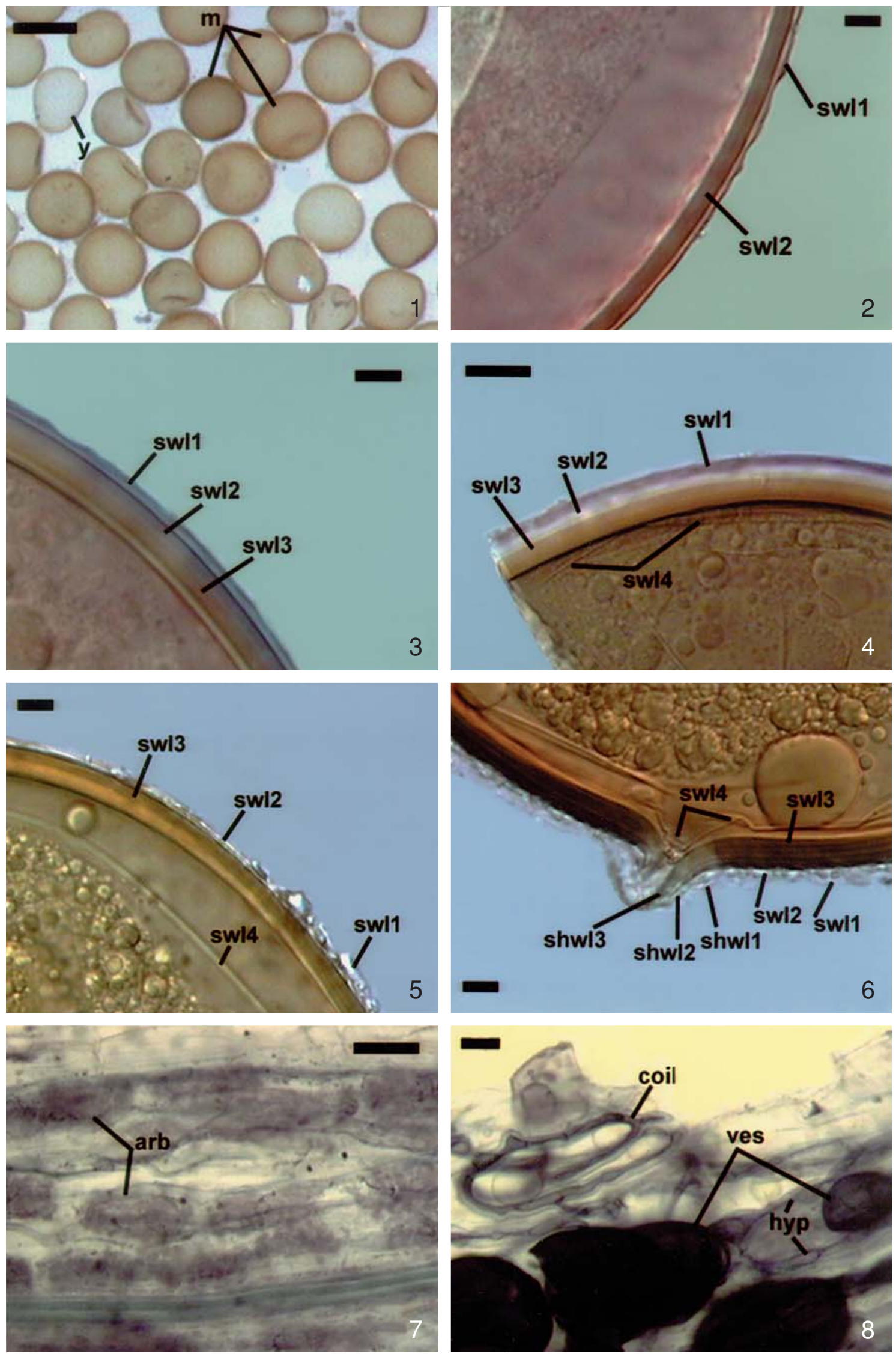

Figs 1-8. Morphology of intact spores, subcellular structure of crushed spores, and mycorrhizae of Glomus claroideum in Plantago lanceolata roots stained in $0.1 \%$ trypan blue. Fig. 1. Intact young (y) and mature (m) spores. Fig. 2. Spore wall layers 1 (swl1) and 2 (swl2) of a most juvenile spore crushed in a mixture of PVLG and Melzer's reagent. Fig. 3. Spore wall layers 1-3 (swl1-3) of a juvenile spore crushed in a mixture of PVLG and Melzer's reagent. Fig. 4. Spore wall layers 1-4 (swl1-4) of a young spore. Fig. 5. Spore wall layers 1-4 (swl1-4) of a mature spore; note the highly deteriorated layer 1. Fig. 6. Spore wall layers 1-4 (swl 1-4) of a mature spore and wall layers 1-3 (shwl1-3) of its subtending hypha; note the invaginated spore wall layer 4 forming a curved septum in the subtending hypha. Fig. 7. Arbuscules. Fig. 8. Vesicles (ves), intraradical hyphae (hyp), and coil (coil). Figs 1, 7, 8, bright field microscopy; Figs 2-6, differential interference contrast. Bars: Figs 2, 3, 5, $6=10 \mu \mathrm{m}$; Figs 4, 7, $8=20 \mu \mathrm{m}$; Fig. $1=150 \mu \mathrm{m}$. 
Apart from the sites of occurrence of G. claroideum listed above, in Poland this fungus was earlier recognized near Chrzanów. However, this record was based only on results of molecular investigations of mycorrhizal roots of $F$. vesca; no spores were revealed.

Glomus claroideum has originally been described from spores recovered from under Glycine $\max$ (L.) Merr. cultivated in Florida (Schenck and Smith 1982). According to Walker and Vestberg (1998), this fungus is widely distributed in Northern Europe, whereas only two reports exist of its presence in the southern hemisphere. Saito and Vargas (1991) revealed G. claroideum spores in cultivated soils of Japan.

Mycorrhizal associations: In the field, G. claroideum spores occurred among vesicular-arbuscular mycorrhizal roots of A. sativa, B. vulgaris, B. napus, B. oleraceae, $F$. vesca, $H$. vulgare, $S$. cereale, $T$. aestivum, $x$ Triticosecale, and $Z$. mays. The mycorrhizae produced by this fungus in single-species pot cultures with $P$. lanceolata as the plant host consist of arbuscules, vesicles, as well as intra- and extramatrical hyphae (Figs 7, 8). Arbuscules are numerous, evenly distributed along the roots and stain pale violet (17A3) to greyish violet (17C5) in $0.1 \%$ trypan blue (Fig. 7). Vesicles are ellipsoid, 45-85 $\times 55-105 \mu \mathrm{m}$ and stain pale violet (18A3) to bluish violet (18A7) in trypan blue (Fig. 8). Intraradical hyphae (Fig. 8) grow parallel to each other and to the root axis, are 2.6-9.1 $\mu \mathrm{m}$ wide, and stain pale violet (17A3-A5). The hyphae frequently form coils, especially at entry points (Fig. 8). The coils are 10.0-13.7 $\times$ 18.6-25.1 $\mu \mathrm{m}$ and stain pale violet (17A3) to greyish violet (17C6).

Discussion: Most juvenile spores of G. claroideum have a two-layered wall with layers 1 and 2 present (Fig. 2). Each next layer (layers 3 and 4) starts to form when the differentiation of the preceding layer was completed. This pattern of differentiation of the subcellular structure of a spore corresponds to that revealed in all Glomus spp. so far investigated ontogenetically (e.g., Błaszkowski and Tadych 1997; Stürmer and Morton 1997).

The most distinctive property of G. claroideum spores is their innermost, flexible wall layer (Figs 4-6). This layer easily separates from the penultimate laminate layer in most crushed spores coming from living pot cultures. However, in spores recovered from field-collected soils, it usually tightly adheres to the laminate layer and, thereby, is invisible in most crushed spores.

Another important wall component of $G$. claroideum spores is the outermost mucilagenous layer 1 (Figs 2-6). This layer is a short-lived structure and usually is present only in young spores. It sloughs with age and the rate of its disintegration probably mainly depends on the microbiological activity of the soil. This layer is colourless and tightly adheres to spore wall layer 2. Hence, it is difficult to see in spores crushed in pure PVLG. The presence of this layer reveals its staining reaction in Melzer's reagent (Figs 2-4).

The semiflexible layer 2 may be also easily omitted. It is thin, usually tightly adheres to the laminate layer 3, and does not stain in Melzer's reagent (Figs 2-6). This layer deteriorates with age as well, although its longevity is much higher than that of layer 1 .

Layer 3 is permanent and coloured (Figs 3-6). It consists of very thin, coloured sublayers, sometimes separating in vigorously crushed young and overmatured spores. This makes an impression of the presence of an additional layer in spore wall structure of this fungal species. Examination of many restrainedly crushed spores of different maturity excludes the five-layered version of the wall structure of this species.

The three-layered wall of subtending hypha of G. claroideum spores is usually visible only in specimens with the two outer spore wall layers present, with which they are continuous (Fig. 6).

The lumen of subtending hypha in some spores of $G$. claroideum is closed by a plug, although the spore content is held by the continuous innermost spore wall layer forming an endospore (Fig. 6).

When observed under a dissecting microscope, spores of $G$. claroideum resemble those of G. luteum Kennedy et al., G. geosporum, G. versiforme (Karsten) Berch, G. clarum Nicol. et Schenck, G. caledonium, and G. etunicatum Becker et Gerd. All the species form yellow to yellow-brown coloured spores of a more or less overlapping size range.

Examination of the structure and biochemical properties of spore wall of specimens of different maturity readily divides these species into three groups. The first group represents G. luteum, which produces spores with both the outermost mucilagenous layer and the innermost flexible layer of G. claroideum (Kennedy et al. 1999). The second group comprises G. clarum, G. caledonium, and G. etunicatum, which link the outermost mucilagenous layer (Morton 1996; Stürmer and Morton 1997). Glomus geosporum and G. versiforme form the third group; the outermost layer of their spores sloughs, but is non-reactive in Melzer's reagent (Morton 2000; Walker 1982).

The properties distinguishing G. claroideum and G. luteum are the thicker and more persistent layer 2 and the thicker layer 3 of spores of the latter species (Kennedy et al. 1999). The thicker laminate layer 3 causes G. luteum spores to be darker coloured than those of G. claroideum.

The unique feature of spores of $G$. clarum is their persistent, rigid, laminate, thick, and colourless layer 2 (Nicolson and Schenck 1979; Stürmer and Morton 1997). Layer 2 of spores of G. claroideum is hyaline as well, but it is much thinner and deteriorates with age. Additionally, spores of G. clarum may be larger than those of G. claroideum.

Apart from the outermost mucilagenous layer, the laminate structural layer of $G$. caledonium is still overlaid by two permanent, rigid, hyaline layers (Morton 1996), whereas only one, impermanent, semiflexible layer exists between the laminate layer and the outermost mucilagenous one of G. claroideum spores.

The wall structure of spores of $G$. etunicatum consists of only two layers (Stürmer and Morton 1997), lacking layers 2 and 4 of $G$. claroideum spores.

Although G. geosporum differentiates an innermost layer adhering to the lower surface of the laminate structural layer as G. claroideum does, this layer in the former species is coloured, rigid, and rarely separates from the laminate layer (Morton 2000; Walker 1982; vs. it is colourless, flexible, and usually separates from the laminate layer in G. claroideum). Additionally, mature spores of G. geosporum usually are darker coloured than those of $G$. claroideum.

In contrast to the outermost wall layer of G. claroideum spores, that of spores of $G$. versiforme is non-reactive in Melzer's reagent, much more persistent, and may be lightcoloured (Błaszkowski, pers. observ.; Morton 2000). Mo- 
reover, the wall of $G$. versiforme spores consists of only two layers (vs. four layers in G. claroideum).

Glomus versiforme differs also from all the other fungal species compared here in properties of its mycorrhizae. They stain only faintly in the commonly used stains (Błaszkowski, pers. observ.; Morton 2000), whereas the staining reaction of those of the other fungal species is intensive (Błaszkowski, pers. observ.; Kennedy et al. 1999; Morton 2000).

In the recently proposed classification of arbuscular mycorrhizal fungi (Schüßler et al. 2001), G. claroideum together with $G$. clarum and G. etunicatum are within group B, whereas G. caledonium and G. geosporum represent group A of the order Glomerales. Glomus versiforme is a member of Diversisporaceae fam. ined.
Glomus spurcum Pfeiffer et al. emend. Kennedy et al.

Sporocarps unknown. Spores borne singly in the soil (Fig. 9); produced from straight sporophores. Sporophore coenocytic to sparsely septate; hyaline to yellowish white (4A2); (1.8-)3.4(-5.6) um wide; with a wall (0.3-)0.5(-0.7) $\mu \mathrm{m}$ thick; bearing spores by swelling at hyphal tips. Mature spores hyaline to pale yellow (4A3); globose to subglobose; (75-)86(-110) $\mu \mathrm{m}$ diam; with a single subtending hypha (Fig. 9). Subcellular structure of spores consists of one wall (Figs 10-14) with two layers (layers 1-2). Outermost layer 1 permanent, flexible, hyaline to pale yellow (4A3), (0.9-)1.0(-1.2) $\mu \mathrm{m}$ thick, frequently ballooning in lactic acid-based mountants (Figs 10-14). Layer 2 laminate, hyaline, smooth, (1.6-)4.5(-5.4) $\mu \mathrm{m}$ thick, composed of very thin, $<0.5 \mu \mathrm{m}$ thick, tightly adherent sublayers (Figs 10-
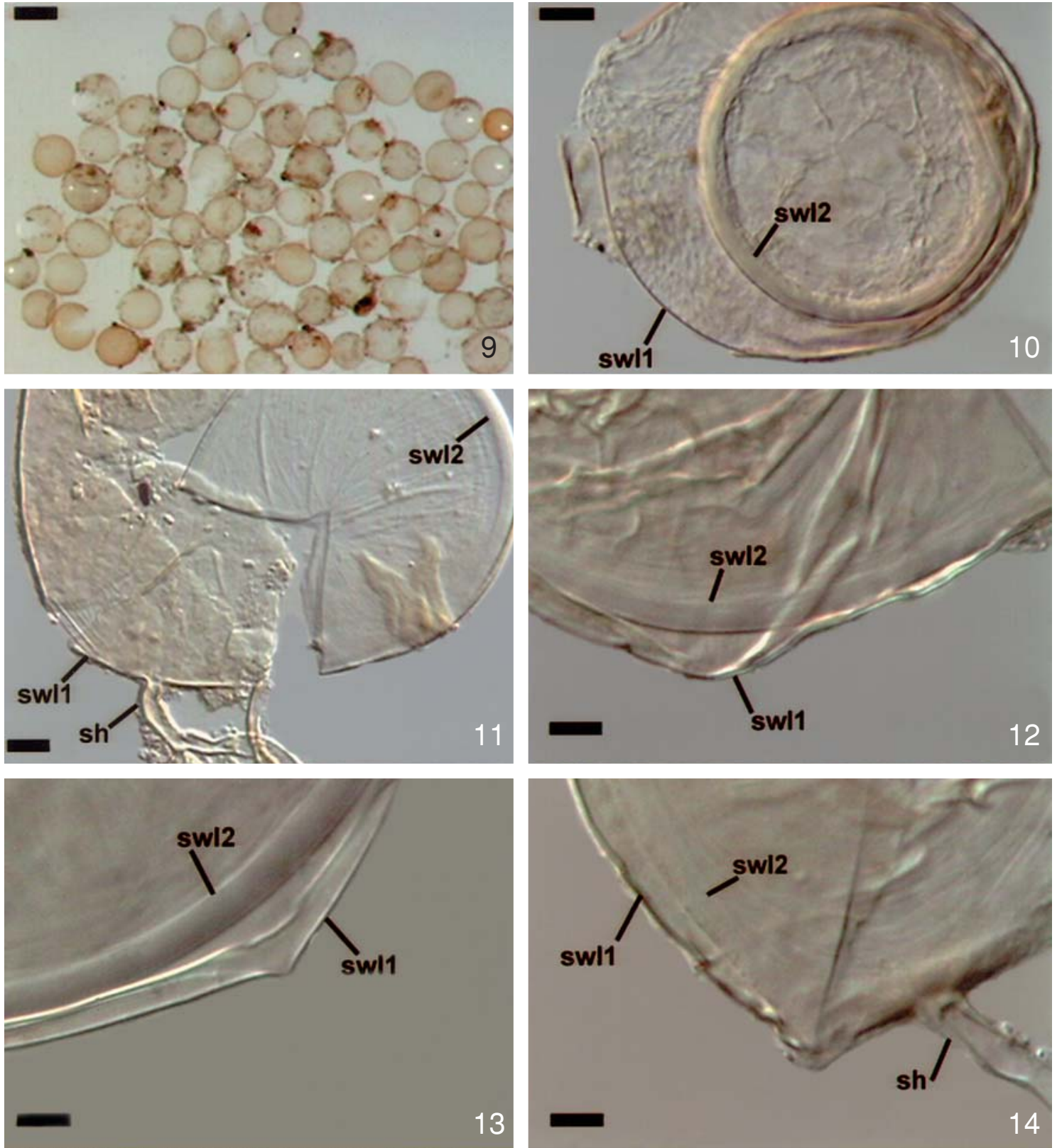

Figs 9-14. Morphology of intact spores and subcellular structure of crushed spores of Glomus spurcum. Fig. 9. Intact spores. Fig. 10. Ballooned spore wall layer 1 (swl1) separated from spore wall layer 2 (swl2). 11. Spore wall layer 1 (swl1) and subtending hypha (sh) completely separated from spore wall layer 2 (swl2) in a heavily crushed spore. Fig. 12 and 13. Spore wall layer 1 (swl1) separated from spore wall layer 2 (swl2); note the flexible layer 1. Fig. 14. Spore wall layers 1 and 2 (swl 1 and 2) and subtending hypha (sh). Fig. 9, bright field microscopy; Figs 10-14, differential interference contrast. Bars: Figs $12-14=10 \mu \mathrm{m}$; Figs $10,11=20 \mu \mathrm{m}$; Fig. $9=100 \mu \mathrm{m}$. 
-14), sometimes separating in vigorously crushed spores. None of the spore wall layers stains in Melzer's reagent. Most juvenile spores hyaline, with two-layered wall, each ca. $0.5 \mu \mathrm{m}$ thick. Subtending hypha hyaline to pale yellow (4A3); straight or recurvate; cylindrical; (4.3-)5.6(-7.8) $\mu \mathrm{m}$ wide at the spore base (Figs 11, 14). Wall of subtending hypha hyaline to pale yellow (4A3); (0.9-)1.0(-1.3) $\mu \mathrm{m}$ thick at the spore base; continuous with spore wall layer 1 (Fig. 11); layer 2 of spore wall extends along layer 1 of subtending hyphal wall only very closely at the spore base. Pore 2.9-7.6 $\mu \mathrm{m}$ diam, occluded by a thin septum or a plug.

Collections examined: Poland. Szczecin, from a pot trap culture with root-rhizosphere soil of Ammophila arenaria Link colonizing maritime sand dunes adjacent to Darłówko $\left(54^{\circ} 26^{\prime} \mathrm{N}, 16^{\circ} 23^{\prime} \mathrm{E}\right)$ and $P$. lanceolata as the plant host, 15 May 2002, Błaszkowski J., 2378-2387, DPP.

Other materials examined: Spores from trap cultures with mixtures of root and rhizosphere soils of $B$. vulgaris and T. aestivum cultivated in Drzemin, Kołbacz and Stobno in the western Pomerania voivodeship, Błaszkowski J., unnumbered collection; spores from trap cultures with root-rhizosphere soils of A. arenaria, Corynephorus canescens (L.) P. Beuv., Elymus arenarius L., Eryngium maritimum L., Festuca rubra L., Phragmites australis (Cav.) Trin. ex Steud., Rubus fructicosus L. nom. Ambig., and Salix sp. colonizing maritime dunes adjacent to Darłówko.

Distribution and habitat: In Poland, spores of G. spurcum were first found in three trap cultures with root-rhizosphere soils of B. vulgaris and T. aestivum cultivated in Drzemin, Kołbacz, and Stobno in the western Pomerania voivodeship. Subsequently, this fungus was revealed in 40 trap cultures containing root-rhizosphere mixtures taken from under A. arenaria, C. canescens, E. arenarius, E. maritimum, F. rubra, P. australis, R. fructicosus, and Salix sp. colonizing maritime dunes adjacent to Darłówko.

The chemical properties of the cultivated soils are as those presented in the section describing the distribution of $G$. claroideum (see above). The chemical properties of the Darłówko dunes ranged: $\mathrm{pH}, 7.6-7.9 ; \mathrm{N}, \mathrm{P}, \mathrm{K}$, and org. C (\%), 0.001-0.002; 0.006-0.009; 0.08-0.09, and 0.01-0.09, respectively.

Glomus spurcum has originally been discovered in a greenhouse bed of sand used for propagation of various ornamental plants cultivated in Arizona (Pfeiffer et al. 1996). This fungus has also been found in maritime dunes of Mexico (Pfeiffer et al. 1996), Hawaii (Koske and Gemma 1996), San Miguel Island, California (Koske, pers. inform.), as well as in different other natural ecosystems of North America, Cuba and Namibia, Africa (Kennedy et al. 1999; Stutz and Morton 1996; Stutz et al. 2000).

Mycorrhizal associations: In the field, spores of G. spurcum were associated with vesicular-arbuscular mycorrhizal roots of two plant species cultivated at three sites of the Western Pomerania voivodeship and eight plant species colonizing the Baltic Sea dunes adjacent to Darłówko. The species of cultivated plants were B. vulgaris and T. aesti$v u m$, and those growing in the dunes included $A$. arenaria, C. canescens, E. arenarius, E. maritimum, F. rubra, P. australis, R. fructicosus, and Salix sp. The arbuscular mycorrhizal fungal species accompanying $G$. spurcum in the field and trap cultures were $G$. aggregatum, $G$. arenarium Błaszk., G. claroideum, G. constrictum, G. lamellosum Dalpé et al., G. mosseae, G. pustulatum Koske et al., and an unidentified Scutellospora sp.

Many attempts to establish mycorrhizae of this fungus in one-species pot cultures with $P$. lanceolata as the plant host failed.

Discussion: The wall of most juvenile spores of $G$. spurcum consists of two, loosely adherent layers. With age, layer 1 darkens and layer 2 thickens due to the synthesis of new, hyaline sublayers in the laminate inner layer.

The spores of G. spurcum most distinguish the easy separation of the outer layer from the inner component of their spores. The outer spore wall layer is continuous with the wall of subtending hypha. In contrast to most species of the genus Glomus, the laminate layer of G. spurcum spores is present in the wall structure of their subtending hypha only closely at the spore base. Thus, the structural support of the hypha formed by the laminate layer is weak. Therefore, layer 1 of a spore and its subtending hyphal wall usually completely separates from the inner laminate spore wall.

The laminate spore wall consists of colourless sublayers, sometimes stratifying in vigorously crushed spores. This makes an impression of the presence of an additional layer and probably resulted in the erroneous conclusion expressed in the original protocol of this species. Examination of the separated fragments shows no differences in their phenotypic properties compared with those of the other, intact part of the laminate layer. Additionally, crushing of many spores by applying different pressure on the cover slip demonstrates a relatively loose nature of the laminate layer and supports the Kennedy's et al. (1999) interpretation of a two-layered spore wall structure of this fungus.

The fungal species morphologically most similar to $G$. spurcum are G. albidum Walker et Rhodes, G. eburneum Kennedy et al., G. gibbosum Błaszk., G. viscosum Nicolson, and Paraglomus occultum (Walker) Morton et Redecker. These species produce hyaline to light-coloured spores of a similar size when observed under a dissecting microscope.

However, G. albidum forms spores with a wall composed of an outer evanescent layer and an inner laminate layer (Walker and Rhodes 1981). Both layers have a similar thickness. In contrast, the outer layer of G. spurcum spores is permanent and much thinner than the inner laminate layer. Young spores of G. albidum stain pink to orange in Melzer's reagent, whereas those of G. spurcum are non-reactive in this reagent.

The property distinguishing G. eburneum is the formation of ovoid to tear-drop shaped spores (Kennedy et al. 1999). Spores of G. spurcum consistently are globose. However, the main differences between these fungi hide in the properties of spore wall layers, which are evident only in heavily crushed spores. The outer layer of $G$. eburneum spores remains adherent to the inner laminate one, and the permanent layer 1 and the laminate layer 2 of the G. spurcum spore wall usually completely separate from each other. Additionally, most vigorously crushed spores of $G$. spurcum are devoid of subtending hypha that along with layer 1 of spore wall separates from the laminate spore wall layer forming too weak structural support of the hypha.

Layers 2 and 3 of spore wall of G. gibbosum are similar to layers 1 and 2 of spore wall of G. spurcum (Błaszkowski 1997). However, in the former species, layer 2 is still associated with an outer evanescent layer, and the laminate lay- 
er 3 surrounds a flexible, colourless innermost layer that is lacking in the latter fungus.

Spores of G. viscosum occur in loose aggregates (Walker et al. 1995) rather than singly in the soil as those of $G$. spurcum. The spore wall of $G$. viscosum consists of three layers with the outermost one exuding a mucigel-like substance (this phenomenon does not occur in G. spurcum). Glomus viscosum also has a persistent subtending hypha (vs. it usually is absent in crushed spores of G. spurcum).

Spores of $P$. occultum remain hyaline throughout their life cycle (Morton and Redecker 2001; Walker 1982). In contrast, mature spores of G. spurcum usually are pale yellow. Additionally, the wall of $P$. occultum spores consists of three layers of equal thickness, whereas the outer spore wall layer of $G$. spurcum is much thinner than the inner one. Finally, the innermost layer of $P$. occultum is a permanent structure lacking sublayers (vs. a laminate layer in $G$. spurcum).

\section{ACKNOWLEDGMENTS}

This study was partly supported by State Committee for Scientific Research, grant no. 6.P04G.100.19.

\section{LITERATURE CITED}

BŁASZKOWSKI J. 1997. Glomus gibbosum, a new species from Poland. Mycologia 89: 339-345.

BŁASZKOWSKI J., TADYCH M. 1997. Glomus multiforum and G. verruculosum, two new species from Poland. Mycologia 89: 804-811.

GERDEMANN J.W., NICOLSON T.H. 1963. Spores of mycorrhizal Endogone species extracted from soil by wet sieving and decanting. Trans. Brit. Mycol. Soc. 46: 235-244.

KENNEDY L.J., STUTZ J.C., MORTON J.B. 1999. Glomus eburneum and G. luteum, two new species of arbuscular mycorrhizal fungi, with emendation of G. spurcum. Mycologia 91: 1083-1093.

KORNERUP A., WANSCHER J.H. 1983. Methuen handbook of colour. 3rd Ed. E. Methuen and Co., Ltd., London. 252 pp

KOSKE R.E., GEMMA J.N. 1996. Arbuscular mycorrhizal fungi in Hawaiian sand dunes: Island of Kaua'i. Pacific Sci. 50: 36-45.

KOSKE R.E., TESSIER B. 1983. A convenient, permanent slide mounting medium. Mycol. Soc. Amer. News Lett. 34: 59.

MORTON J.M. 1996. Redescription of Glomus caledonium based on correspondence of spore morphological characters in type specimens and a living reference culture. Mycorrhiza 6: 161-166.

MORTON J.B. 2000. International Culture Collection of Arbuscular and Vesicular-Arbuscular Mycorrhizal Fungi. West Virginia University.
MORTON J.B., REDECKER D. 2001. Two families of Glomales, Archaeosporaceae and Paraglomaceae, with two new genera Archaeospora and Paraglomus, based on concordant molecular and morphological characters. Mycologia 93: 181-195.

NICOLSON T.H., SCHENCK N.C. 1979. Endogonaceous mycorrhizal endophytes in Florida. Mycologia 71: 178-198.

PFEIFFER C.M., WALKER C., BLOSS H.E. 1996. Glomus spurcum: a new endomycorrhizal fungus from Arizona. Mycotaxon 59: 373-382.

PHILLIPS J.M., HAYMAN D.S. 1970. Improved procedures for clearing roots and staining parasitic and vesicular-arbuscular mycorrhizal fungi for rapid assessment of infection. Trans. Brit. Mycol. Soc. 55: 158-161.

SAITO M., VARGAS R. 1991. Vesicular-arbuscular mycorrhizal fungi in some humus-rich Ando soils of Japan. Soil Microorg. 38: 3-15.

SCHENCK N.C., SMITH G.S. 1982. Additional new and unreported species of mycorrhizal fungi (Endogonaceae) from Florida. Mycologia 74: 77-92.

SCHÜßLER A. SCHWARZOTT D., WALKER C. 2001. A new fungal phylum, the Glomeromycota: phylogeny and evolution. Mycol. Res. 105: 1413-1421.

SPAIN J.L., SIEVERDING E., SCHENCK N.C. 1989. Gigaspora ramisporophora: a new species with novel sporophores from Brazil. Mycotaxon 34: 667-677.

STÜRMER S.L., MORTON J.B. 1997. Developmental patterns defining morphological characters in spores of four species in Glomus. Mycologia 89: 72-81.

STUTZ J.C., MORTON J.B. 1996. Successive pot cultures reveal high species richness of arbuscular mycorrhizal fungi in arid ecosystems. Can. J. Bot. 74: 1883-1889.

STUTZ J.C., COPEMAN R., MARTIN C.A., MORTON J.B. 2000. Patterns of species composition and distribution of arbuscular mycorrhizal fungi in arid regions of southwestern North America and Namibia, Africa. Can. J. Bot. 78: 237-245.

TURNAU K., RYSZKA P., GIANINAZZI-PEARSON V., VAN TUINEN D. 2001. Identification of arbuscular mycorrhizal fungi in soils and roots of plants colonizing zinc wastes in southern Poland. Mycorrhiza 10: 169-174.

WALKER C. 1983. Taxonomic concepts in the Endogonaceae: Spore wall characteristics in species descriptions. Mycotaxon 18: 443-455.

WALKER C., RHODES L.H. 1981. Glomus albidus: a new species in the Endogonaceae. Mycotaxon 12: 509-514.

WALKER C., GIOVANNETTI M., AVIO L., CITERNESI A.S., NICOLSON T.H. 1995. A new fungal species forming arbuscular mycorrhizas: Glomus viscosum. Mycol. Res. 99: 1500-1506.

WALKER C., VESTBERG M. 1998. Synonymy amongst the arbuscular mycorrhizal fungi: Glomus claroideum, G. maculosum, G. multisubstenum and G. fistulosum. Ann. Bot. 82: 601-624. 


\section{GLOMUS CLAROIDEUM I G. SPURCUM, ARBUSKULARNE GRZYBY MIKORYZOWE (GLOMERALES) NOWE ODPOWIEDNIO DLA POLSKI I EUROPY}

\section{STRESZCZENIE}

Opisano i zilustrowano rozwój ontogenetyczny i cechy morfologiczne zarodników dwóch gatunków arbuskularnych grzybów mikoryzowych (Glomeromycota) z rodzaju Glomus, G. claroideum i G. spurcum. Zarodniki obu gatunków nie były wcześniej znajdywane w Polsce, a niniejszy artykuł jest pierwszym doniesieniem o występowaniu G. spurcum w Europie.

Mikoryzy Glomus claroideum wytworzone w jednogatunkowej kulturze z Plantago lanceolata składają się $\mathrm{z}$ arbuskul, wezykul, jak również strzępek wewnątrz- i zewnątrzkorzeniowych barwiących się intensywnie w błękicie trypanowym. Nie określono mikoryz G. spurcum, ponieważ liczne próby ustanowienia jednogatunkowych kultur tego gatunku nie powiodły się. Ponadto przedstawiono rozmieszczenie obu grzybów w świecie.

SŁOWA KLUCZOWE: grzyby arbuskularne, Glomeromycota, mikoryzy. 